\title{
The life of a marginal basin depicted in a structural map of the South China Sea
}

\author{
${ }^{1}$ CNRS-UMR8538, Ecole Normale Supérieure de Paris, Laboratoire de Géologie, 24 Rue Lhomond, 75231 Paris, CEDEX 5, France; \\ *Corresponding author, E-mail:manu_pub@mailhost.geologie.ens.fr \\ ${ }^{2}$ National Institute of Geological Sciences (NIGS), College of Science, University of the Philippines, Velazquez Street, U.P. Campus, Diliman, \\ Quezon City 1101, Philippines \\ ${ }^{3}$ Ecole Normale Supérieure de Paris, Laboratoire de Géologie, 24 Rue Lhomond, 75231 Paris, CEDEX 5, France
}

(Received: October 24, 2017; Revised accepted: June 18, 2018)

https://doi.org/10.18814/epiiugs/2018/018014

The South China Sea (SCS) is presented here as a case example to demonstrate the evolution of basins developed at convergent boundaries. The structural map published in 2017 by CGMW at the 1:3 million scale allows to visualize the location of the rifting faults from a normal to hyper-extended crust, the shape and structure of the oceanic crust and their late involvement in a convergent margin. It highlights the reactivation of the Mesozoic tectono-stratigraphic setting such as broad folds and granitic plutons during the rifting, and the effect of the resulting architecture on the $N W$ Borneo accretionary wedge.

\section{Introduction}

Like most of the basins of SE Asia, the South China Sea (SCS hereafter) developed by rifting from the Palaeogene (Taylor and Hayes, 1980) and suffered shortening starting from the Middle Miocene, as a result of the variations of stress imposed by the neighboring subductions. Because of its narrow V-shaped oceanic crust, the wide extension of its rifted continental crust, and the various styles of rifting, the SCS basin is a text-book subject to study the formation of passive margins developed over former subduction zones. In addition, the SCS has been the focus of scientific interest in past decades (Katili, 1981) including ODP (Leg 184) and recent IODP (Leg 349, Li et al., 2015) drillings, oil and gas exploration, and projects from several international teams onshore and offshore, which supplied a great deal of seismic and other geophysical and geological data (Franke et al., 2014; Sibuet et al., 2016). It benefits nowadays from one of the most extensive geophysical coverage in the world. The basin structures have been recently compiled on a structural map by a large group of experts of the region. This map highlights the basement structures related to the Late Cretaceous to Middle Miocene extension as well as the late evolution of the basin, associated with shortening features on its southern side.

\section{The Structural Map}

If geological maps depict as accurately as possible the structures and geological formations according to their age, the principle of superposition of strata makes it difficult to see the tectonic events covered by basins, platforms or recent sedimentary deposits. On the other hand, tectonic maps which group into time brackets the corresponding tectonic events or orogenies, also take into account the lithologies and metamorphic conditions. However they become complex when several events are superimposed.

On the Structural Map of the South China Sea (Pubellier et al., 2017) based on a large amount of industrial and academic data, an effort was made to select the main structures and lithologies having played a key role in the formation and the evolution of the SCS. The color code was designed in order to facilitate the offshore/onshore correlation of the structural units. The basement rocks older than the Jurassic were not differentiated and an emphasis was given to the Mesozoic granitoids and older magmatic and metamorphic rocks as well as the Cenozoic volcanic edifices onshore and offshore which have been deposited both on the margins and the sea-floor. The main crustal structural entities were distinguished as thick continental basement, stretched continental crust, inferred zones of exhumed mantle (even below the post-rift sediments), volcanic arc crust in the Philippines, and oceanic crust. Sedimentary bodies onshore and offshore are wedges, platforms and basins, as well as the extent of the Mesozoic marine environment. The age of the crust in the basins other than the SCS (e.g., Celebes Sea, Sulu Sea) is not specified. Rifted Cenozoic basins are underlined and post-Mid Miocene basins appear transparent over rifted structures. Instead of showing the picks or the models of the debated magnetic anomalies, the map depicts the non-controversial magnetic anomalies and emphasizes on the structural fabrics of the sea-floor. The faults represented as black normal faults on the map are those associated with the crustal extension since the beginning of the Late Cretaceous. Other faults, which may appear crossing or paralleling the rifting faults are reversed or thrust faults which mostly took place during the Middle Miocene and the Pliocene. The thin red faults emphasize the shallow-rooted faults which character- 
ized the gravity tectonic processes that affected the thick Miocene deltas of the SCS.

\section{Geological Features Linked to Extensional His- tory}

The basement, which is similar in China, Vietnam and part of the western Philippines is undifferentiated on the map. During Mesozoic times, the area was sitting on the upper plate of a subduction zone, resulting in an impressive coverage of Cretaceous granites sometimes separated by narrow Cretaceous molasse basins. These granitic bodies, widespread offshore in the extended crust conditioned the location of the extension via large detachments and normal faults; later cut by steeper faults. The geometries of the faults vary from E-W to NESW indicating that the rifting underwent several stages with different stretching directions. The extension started during Late Cretaceous before the rifting sensu stricto which is clearly documented since the Early Eocene only. Stretching and thinning were important and resulted in a wide "Basin and Range" like province (Franke et al., 2014; Pichot et al., 2014) which was sustained near sea level during the entire duration of the rifting process. This province is seen on both margins of the SCS and ultimately exhumed the mantle like in offshore Vietnam and SE of Taiwan. Some faults are low angle detachments and surround the granitic and metamorphic basement. The structure of the margin by the end of the rifting is dominated by a severe boudinage of a thin crust (Savva et al., 2014), on which the low-angle normal faults are either the granitoids boundaries or the short limbs of Cretaceous folds. Reactivation of early structures is common during rifting or basin inversion (Festa et al., 2015; Balestro et al., 2018). Because the thinned margin was sustained at shallow depth, platform and reef carbonates occupy some of the bathymetric highs. Their development occurred mainly during Late Oligocene to Mid Miocene and during Late Miocene times. The oceanic crust of the SCS was represented with the generally accepted main magnetic anomalies (Briais et al., 1993; Sibuet et al., 2016). The areas where the crust is younger with controversial age is shown with a different color according to recent models. The geometry of the ocean floor basin has a "V" shape configuration, which ends to the SW as a propagator, implying that the age of the crust (and therefore the breakup) may be diachronic. It is possible that part of the NW Sulu Sea is actually floored by an oceanic crust which could represent a relic of the Proto South China Sea, to be correlated with the Palawan ophiolite.

The SCS basin also raises questions about the time of the breakup and the time of cessation of the extension. The spreading of oceanic crust started by $33 \mathrm{Ma}$ in the northern and central part of the basin although rifting continued until at least $15.5 \mathrm{Ma}$, at a time when spreading was already finishing (Franke et al., 2014). Furthermore extension is also observed in the midst of the oceanic crust as indicated by low angle normal faults. It is only during early Late Miocene times (circa $12 \mathrm{Ma}$ ) that extension ceased and regional subsidence was triggered, and marked by a well-known Mid Miocene unconformity (MMU). The unconformable Late Miocene series are indicated on the map; they also seal the late structures of the collision along the NW Borneo Wedge.

\section{Geological Features Linked to Shortening His- tory}

When the SCS basin subsided during the Late Miocene, the NW Borneo wedge started to rise quickly resulting in its subsequent erosion. Likewise other places in the world, the reactivation of crustal heterogeneities during extension and their implication in the later shortening (Festa et al., 2015) is well expressed in the SCS. It has been documented that the compression which marks the end of the subduction of the Proto South China Sea is responsible for the thrusting of the NW Borneo wedge onto the southern margin of the SCS by the Middle Miocene. This wedge is dominated by two large tectonic units which represent the distal sedimentary series (Rajang wedge) and the proximal series (Crocker Wedge) deposited on the shelf of the conjugate block of the SCS (Palawan-Luconia Block). There is evidence that wedging in Middle Miocene (Pagasa Wedge) may have extended to the north in SW Palawan, albeit at a lower magnitude (Aurelio et al., 2014). The consequence of the probable slab detachment of the subducted Proto South China Sea slab, and the thrusting of the NW Borneo wedge on this later block induced thickening and uplift, which in turn generated sub-aerial conditions for the NW Borneo wedge. The resulting erosion created the large deltas of Champion, Balingan, and Baram, starting from the end of the Early Miocene. Excess of sediment loading in the deltas induced gravity tectonics (Sapin et al., 2012). The resulting gravity provinces are characterized by red faults which include growth faults and toe-thrusts affecting generally the mid-Miocene to Recent sedimentary pile.

\section{Lessons Learned from the SCS Case Study}

Detailed geological mapping and the here presented synthesis of geodynamic of the SCS indicates that some accepted concepts of rifted basins must be handled with care. Among these are 1) the varying age of the breakup, highlight that extension may start before the rifting (orogenic collapse of former topography), and may continue long after the rifting has ceased, 2) the long lasting continental or shallow marine conditions without regional subsidence, 3) and the late crustal rebound associated with the end of the neighboring subduction, which may trigger high vertical motion and develop large deltas prone to gravity tectonics.

\section{Acknowledgements}

With contributions from :Dimitri Savva (ENS), François Sapin (TOTAL), Dieter Franke (BGR), Van Phach Phung (VAST), Jean-Luc Auxiètre, Lung Sang Chan (HKU), Florian Meresse (ENS), Benjamin Sautter (ENS), Virginie Le Gal (ENS), Kristine Taguibao (NIGS), Char-Shine Liu (NTU), Stephan Steuer (BGR), Yazid Mansor (UTP), David Menier (UBS), Kirk Mcintosh (U Texas), Jean Claude Sibuet, Nicolas, Chamot-Rooke (ENS), Van Tri Tran (IGMR-Vietnam), Mazlan Madon (PETRONAS), Herman Darman (SHELL). 


\section{References}

Aurelio, M., Forbes, M.T., Taguibao, K.J.L., Savella, R.B., Bacud, J.A., Franke, D., Pubellier, M., Savva, D., Meresse, F., Steuer, S., and Carranza, C.D., 2014, Middle to Late Cenozoic tectonic events in south and central Palawan (Philippines) and their implications to the evolution of the south-eastern margin of South China Sea: evidence from onshore structural and offshore seismic data. Journal of Marine and Petroleum Geology, v. 58, pp. 658-673.

Balestro, G., Festa, A., Borghi, A., Castelli, D., and Tartarotti, P., 2018, Role of Late Jurassic intra-oceanic structural inheritance in the Alpine tectonic evolution of the Monviso meta-ophiolite Complex (Western Alps). Geological Magazine, v. 155, pp. 233-249.

Briais, A., Patriat, P., and Tapponnier, P., 1993, Updated interpretation of magnetic anomalies and seafloor spreading stages in the South China Sea: implications for the Tertiary tectonics of Southeast Asia. Journal of Geophysical Research, Solid Earth, v. 98, pp. 6299-6328.

Festa, A, Balestro, G., Dilek, Y., and Tartarotti, P., 2015, A Jurassic oceanic core complex in the high-pressure Monviso ophiolite (W Alps, NW Italy). Lithosphere, v. 7, pp. 646-652.

Franke, D., Pubellier, M., Steuer, S, Meresse, F., Savva, D., and Auxietre, J.L., 2014, The final rifting evolution in the South China Sea. In: Pubellier, M., Franke, D., McIntosh, K., Menier, D., and Li, C.-F. (Eds.), Evolution, Structure, and Sedimentary Record of the South China Sea and Adjacent Basins. Marine and Petroleum Geology, Special Publication, v. 58, pp. 704-720.

Katili, J.A., 1981, Geology of Southeast Asia with particular reference to the South China Sea. Energy, v. 6, pp. 1077-1091.

Li, C.-F., Lin, J., Kulhanek, D.K., and the Expedition 349 Scientists, 2015, Proceedings of the International Ocean Discovery Program, v. 349: South China Sea Tectonics. International Ocean Discovery Program, College Station, USA, $10 \mathrm{p}$.

Pichot, T., Delescluse, M., Chamot-Rooke, N., Pubellier, M., Qiu, Y., Meresse, F., Sun, G., Savva, D., Wong, K.P., Watremez, L., and Auxiètre, J.L. 2014, Deep crustal structure of the conjugate margins of the SW South China Sea from wide-angle refraction seismic data. Marine and Petroleum Geology, v. 58, pp. 627-643.

Pubellier, M., Savva, D., Sapin, F., and Aurelio, M., 2017, Structural map of the South China Sea (scale 1:3,000,000). Commission for the Geological Map of the World. https://doi.org/10.14682/2017STRUCTUSCS

Ren, J., Niu, B., Wang, J., Jin, X., and Xie, L., 2013, International Geological Map of Asia (scale 1:5,000,000). Commission for the Geological Map of the World. Available at https://ccgm.org/en/home/160-international-geological-map-of-asia-at-15-m-igma-9787116083646.html

Sapin, F., Ringenbach, J.C., Rives, T., and Pubellier, M., 2012, Counterregional normal faults in shale-dominated delta: origin, mechanism and evolution. Marine and Petroleum Geology, v. 37, pp. 121-128.

Savva, D., Pubellier, M., Franke, D., Chamot-Rooke, N., Meresse, F., Steuer, S., and Auxietre, J.L., 2014, Different expressions of rifting on the South China Sea margins. In: Pubellier, M., Franke, D., McIntosh, K., Menier, D., and Li, C.-F. (Eds.), Evolution, Structure, and Sedimentary Record of the South China Sea and Adjacent Basins. Marine and Petroleum Geology, Special Publication, v. 58, pp. 579-598.

Sibuet, J.C., Yeh, Y.C., and Lee, C.H., 2016, Geodynamics of the South China Sea. Tectonophysics, v. 692, pp. 98-119.

Taylor, B., and Hayes, D.E., 1980, The tectonic evolution of the South China Basin. In: Hayes, D.E. (Ed.), The Tectonic and Geologic Evolution of Southeast Asian Seas and Islands. Geophysical Monograph Series, American Geophysical Union, Washington D.C., v. 23, pp. 89-104.

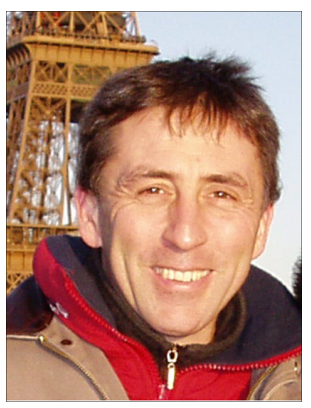

Manuel Pubellier obtained his Ph.D. from the University Pierre \& Marie Curie of Paris in 1987. He worked as a lecturer in the Republic of Haiti (Caribbean) in his early days, and joined the French National Center for Scientific Research (CNRS) in 1988 and became a Research Director at the Laboratory of Geology of the Ecole Normale Supérieure de Paris in 2010. He has a long teaching experience as Visiting Professor at the IFP School and in Universities of Paris, Hong Kong, and UTP in Malaysia. His work is in the field of geodynamics applied to basins formation, and the comparison between geophysical and geological observation of the deformation, particularly in SE Asia. He is currently President of the Commission for the Geological Map of the World (CGMW).

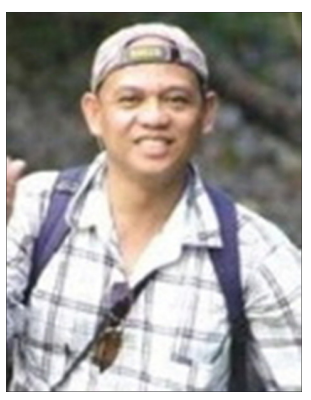

Mario Juan A. Aurelio obtained a B.Sc. Geology degree from the University of the Philippines in 1985 . He went on to obtain a Ph.D. in Structural Geology and Tectonics in 1992 at the Université Pierre et Marie Curie in Paris, France, followed by a Post Doctorate fellowship on Geodynamics through Space Geodesy and Seismotectonics in France and Germany (1994-1995). Prior to joining the academy, Dr. Aurelio worked for 20 years as a geologist at the Mines and Geosciences Bureau (MGB). He is currently Professor at and the Director of the National Institute of Geological Sciences, University of the Philippines (UP-NIGS). He is an Adviser of the Philippine Delegation to the Annual Assembly of the International Seabed Authority and a member of the Philippine Extended Continental Shelf Technical Working Group.

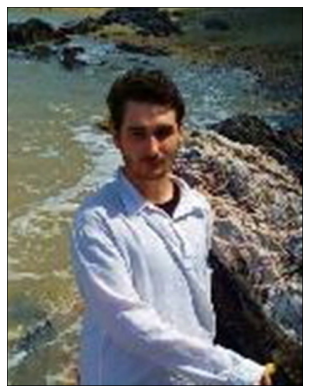

Benjamin Sautter received his Bachelor's degree in Earth Sciences, Environment and Planets from the Institut de Physique du Globe de Paris (IPGP) in 2010, and a Master's degree in Geology and Natural Hazards in 2012. He completed in 2016 a Ph.D. at the Ecole Normale Supérieure de Paris (ENS) in collaboration with the Universiti Teknologi PETRONAS focused on the Late Paleozoic to Present tectonic evolution of the northwestern Malaysia Peninsula. He had previously conducted a study of the geochronology and metamorphism of the internal zone of the Longmen Shan and the cosmogenic dating of alluvial terraces of the Ürümqi River (Tien Shan). His main research interests are Tectonics, Structural Geology and Geochronology. He is now lecturer at the Universiti Teknologi Petronas. 


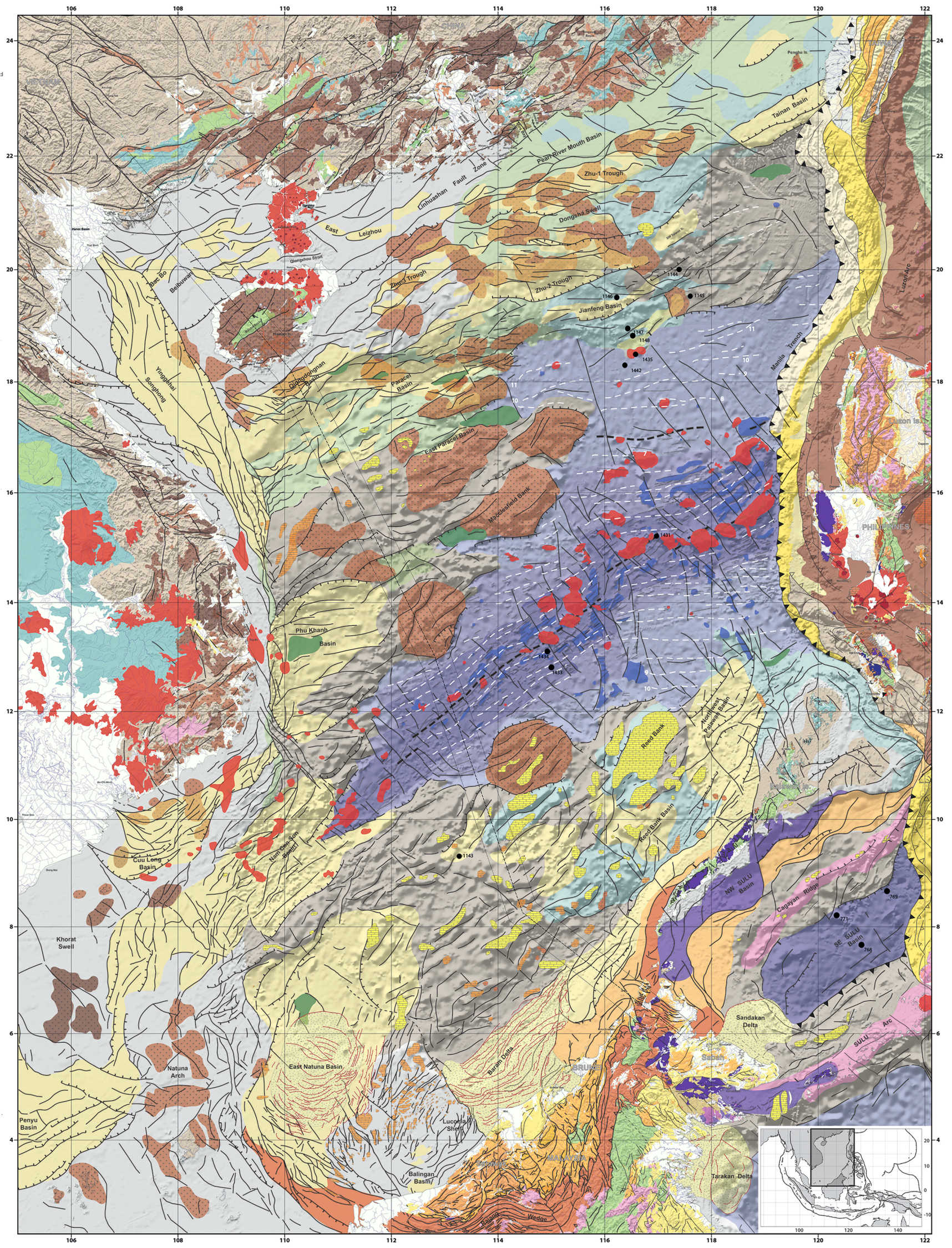

Printed version of the map available at: https://ccgm.org/en/36-oceans

Legend of the map: https://ccgm.org/en/home/183-structural-map-of-the-south-china-sea-9782917310342.html

Price: 20 Euros. 